\title{
ASSESSMENT OF FIREFIGHTING EFFICIENCY OF VEGETATION FIRES IN CURITIBA-PARANÁ
}

\author{
Heitor Renan Ferreira ${ }^{*}$, Antonio Carlos Batista ${ }^{2}$, Alexandre França Tetto ${ }^{2}$ \\ ${ }^{1 *}$ Federal University of Paraná, Graduate Program in Forest Engineering, Curitiba, Paraná, Brazil - e-mail bmheitorf@ gmail.com \\ ${ }^{2}$ Federal University of Paraná, Department of Forest Sciences, Curitiba, Paraná, Brazil - batistaufpr@gmail.com; tetto@ufpr.br
}

Received for publication: 25/05/2020 - Accepted for publication: 12/09/2020

\begin{abstract}
Resumo
Avaliação da eficiência no combate aos incêndios em vegetação em Curitiba-Paraná. Os incêndios em vegetação quando não controlados causam perdas econômicas, eliminação temporária de vegetação, danos ao solo, à fauna e à saúde. Para a melhoria no processo de prevenção e combate aos incêndios, é necessária uma avaliação da atuação dos agentes envolvidos. O objetivo deste estudo foi avaliar a eficiência do combate aos incêndios em vegetação no município de Curitiba, Paraná, no período de 2011 a 2015, mediante registros do Corpo de Bombeiros da Polícia Militar do Paraná. A partir da verificação da consistência e classificação dos registros de incêndios, foram obtidas informações sobre a extensão da área queimada, tempo de primeiro ataque ao incêndio, duração do combate, principais meios de extinção utilizados e quantidade de água utilizada. Os resultados indicaram que $88 \%$ dos registros apresentaram área queimada igual ou inferior a quatro hectares. Ainda, a área média queimada foi de 2.399,21 m², o tempo de ataque médio foi de 14,1 minutos e a duração média de combate foi de 29,9 minutos, valores inferiores aos estudos obtidos de diferentes localidades. Quanto aos meios de extinção, verificou-se que os equipamentos de abafamento e a utilização de água estiveram presentes em 66,4 e 60,6\% dos registros, respectivamente. A quantidade média de água utilizada foi de $1.186,56$ litros por incêndio, evidenciando uma volumetria mínima necessária dos recipientes de armazenamento de água para o combate aos incêndios na área de estudo. Com base nos resultados obtidos foi verificado que o combate aos incêndios em vegetação em Curitiba apresenta uma boa eficiência.

Palavras-chave: Fogo; incêndio florestal; interface urbano-rural.
\end{abstract}

\begin{abstract}
Assessment of firefighting efficiency of vegetation fires in Curitiba-Paraná. Vegetation fires, when not controlled, cause economic disruption, temporary loss of vegetation, and damage to soil, fauna and health. To improve the process of fire prevention and firefighting, it is necessary to evaluate the performance of the involved agents. The objective of this study was to evaluate the firefighting efficiency of vegetation fires in the municipality of Curitiba, Paraná, from 2011 to 2015, using records from the Fire Department of the Military Police of Paraná. Once the consistency of the fire records was verified, they were classified and information was gathered regarding the extent of burnt area, time of first attack, combat time, main fire-extinguishing methods used, and amount of water used. The results indicate that $88 \%$ of the records registered a burnt area inferior or equal to four hectares. In addition, the mean burnt area was of 2,399.21 $\mathrm{m}^{2}$, the mean attack time was of 14.1 minutes, and the mean combat time was of 29.9 minutes, all lower than the ones presented by studies from different locations. As for the fire-extinguishing methods, it was verified that smothering equipment and water were used in 66.4 and $60.6 \%$ of the records, respectively. The mean amount of water used was of 1,186.56 liters per fire, indicating a minimum volume necessary for water storage containers for firefighting in the study area. Based on the results, we concluded that the firefighting of vegetation fires in Curitiba is efficient.

Keywords: Fire; forest fire; wildland-urban interface.
\end{abstract}

\section{INTRODUCTION}

Vegetation fires, which are the result of several factors of natural and socioeconomic origin (FIDALGO, 2013), have been increasingly impacting various regions of the globe, profoundly marking and altering the sites where they occur, and promoting the temporary removal of vegetation. Such impacts cause economic losses and damages to soil, fauna, and the physical and mental health of locals (LOURENÇO et al., 2012; BOWMAN et al., 2011; SOARES et al., 2017).

In general, fires occur when there is a failure in prevention; in turn, their occurrence requires effective firefighting for their extinction (SOARES et al., 2017). In order to improve the process of fire prevention and firefighting, a performance evaluation of the agents involved is needed, which in this case is aided by a reliable database containing information regarding the intervention of the teams that acted in the events (SOARES et al., 2017; LIMA and SOARES, 1992; TETTO et al., 2012b).

According to Vélez (2009), there is a conflict caused by the burning of urban waste (industrial and residential waste) in the wildland-urban interface, since the increase in population density in these areas promotes an increase in the amount of waste from urban concentrations, in addition to diversifying the combustible material. 
The neglect caused by the lack of care in the use of fire in these areas can contribute to the increase in the number of vegetation fires.

Soares et al. (2017) argue that the shorter the time taken between the detection of a fire and the arrival of the team on site, the greater the efficiency achieved will be. Agility in this process will generally provide a greater chance of controlling the fire, as the larger the fire, the more difficult it is to fight it.

In Brazil there are few reliable long-term statistics on areas of greater fire occurrence, fire causes, types of vegetation affected, extent of burnt area, aspects of firefighting, and adequate fire-extinguishing equipment (LIMA and SOARES, 1992). The lack of standardization in the filling of records (TETTO et al., 2012a, LIMA et al., 2018) also makes it difficult to compare and analyse improvements in the processes of preventing and fighting vegetation fires in a given locality.

The municipality of Curitiba has a high spatial index of urban forest and the increase in population density proves to be one of the factors that contribute to the decrease of vegetation cover in certain areas of the municipality (GRISE et al., 2018). This anthropic pressure directs the urban expansion towards rural and natural landscapes, bringing the buildings closer to inflammable vegetation. This hinders firefighting actions (BOWMAN et al., 2011), since the spread of fire towards urbanized areas can promote the ignition of the present infrastructures, thus acting in the wildland-urban interface (FIDALGO, 2013).

The objective of this study was to evaluate the firefighting efficiency of vegetation fires in the municipality of Curitiba, Paraná, from 2011 to 2015, through variables related to firefighting contained in the general occurrence register of the Fire Department of the Military Police of Paraná database.

The hypothesis tested in this study is: the city of Curitiba presents good efficiency in firefighting when compared to other locations due to the availability of fire stations for various emergencies and the peculiarities of its urban areas.

\section{MATERIAL AND METHODS}

The study area is the municipality of Curitiba, located in the state of Parana (Figure 1). Its UTM coordinates are $22 \mathrm{~S} \mathrm{~N} \mathrm{7,186,559} \mathrm{m} \mathrm{and} \mathrm{E} \mathrm{673,674} \mathrm{m,} \mathrm{with} \mathrm{an} \mathrm{average} \mathrm{altitude} \mathrm{of} 934 \mathrm{~m}$, a territorial area of $435.036 \mathrm{~km}^{2}$, and an estimated population for the year 2019 of 1,933,105 inhabitants (IBGE, 2020).

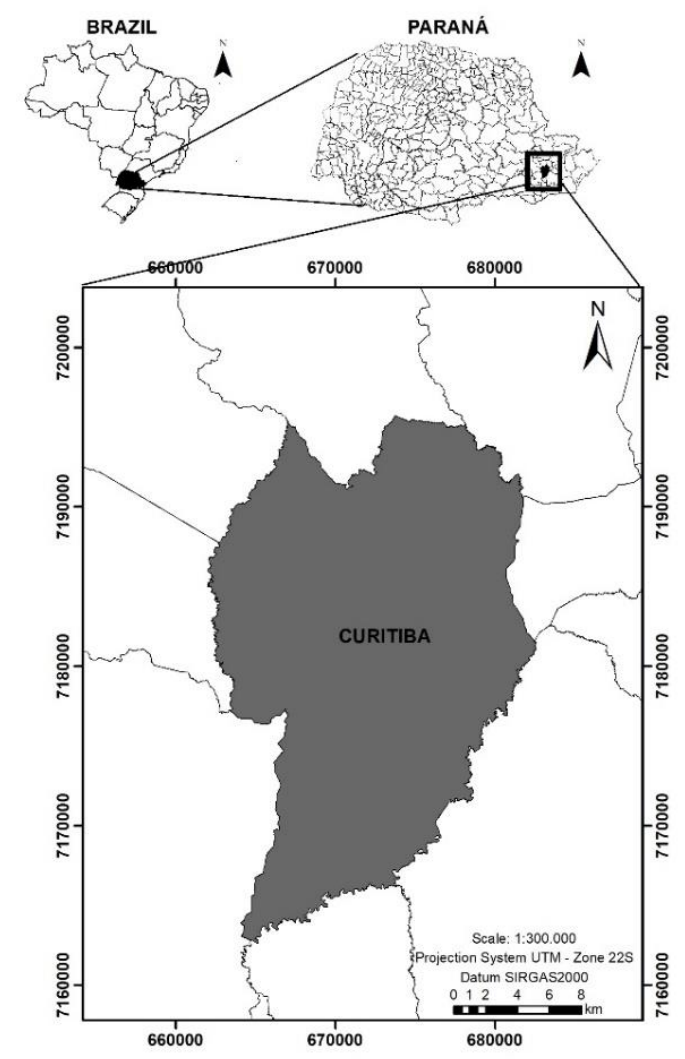

Source: IBGE (2020), prepared by the authors

Figure 1. Location map of the study area.

Figura 1. Mapa de localização da área de estudo. 
Curitiba presents as zonal characteristic the field limit with araucaria forest, currently classified as cultivated area. It has an average annual temperature of $16.5^{\circ} \mathrm{C}$ with the hottest month showing $20.4{ }^{\circ} \mathrm{C}$ and the coldest month $12.7^{\circ} \mathrm{C}$. The month with the highest rainfall volume is January with 190.7 millimeters, while August is the most deficient month with 78.2 millimeters. The average total annual precipitation is 1,451.8 millimeters. According to Koeppen's climate classification, the climate is type $\mathrm{Cfb}$, hot-temperate pluvial climate, with the hottest month below $22{ }^{\circ} \mathrm{C}$, eleven months with the temperature higher than $10{ }^{\circ} \mathrm{C}$, more than five annual frosts, and the rare occurrence of snow (MAACK, 2012).

Also according to the same author, the primitive vegetation of Curitiba was composed of clean fields, characterized by extensive areas of low grasses devoid of shrubs, with the occurrence of limited forests or grasslands in the depressions around springs and water streams. Currently, according to Grise et al. (2018), the municipality has a vegetation cover of $43.69 \%$ of its area, amounting to a total of approximately $189.8 \mathrm{~km}^{2}$ of green area. Despite the existence of predominantly urban characteristics, Curitiba has a total of 123 rural establishments according to the 2017 agricultural census (IBGE, 2020). Each has an average area of 6.06 ha, thus demonstrating the presence of agricultural and forestry crops in the surroundings of the municipality.

In Curitiba, from 2011 to 2015, 10 fire stations were active and distributed in order to ensure greater efficiency in emergency care (SYSBM-CCB, 2016). Generally, each fire station has a fire engine (ABTR) (Figure $2 \mathrm{a}$ ), with a minimum storage capacity of approximately 4,500 liters of water, as well as equipment for the firefighting of vegetation fires, such as: hoses and sprays, hoes, shovels, fire beater, back pumps, and fire control equipment (pinga-fogo). Also, in the most critical periods, from July to September (TETTO et al., 2012a), auxiliary garrisons are activated using Search and Rescue Vehicles (SAR) (Figure 2b), which are pick-ups containing manual equipment similar to those contained in fire engines. In the models in which the SAR vehicle presents water storage in a tank, there is a variation of 500 to 1,000 liters of storage capacity (CORPO DE BOMBEIROS DO PARANÁ, 2020).

a)

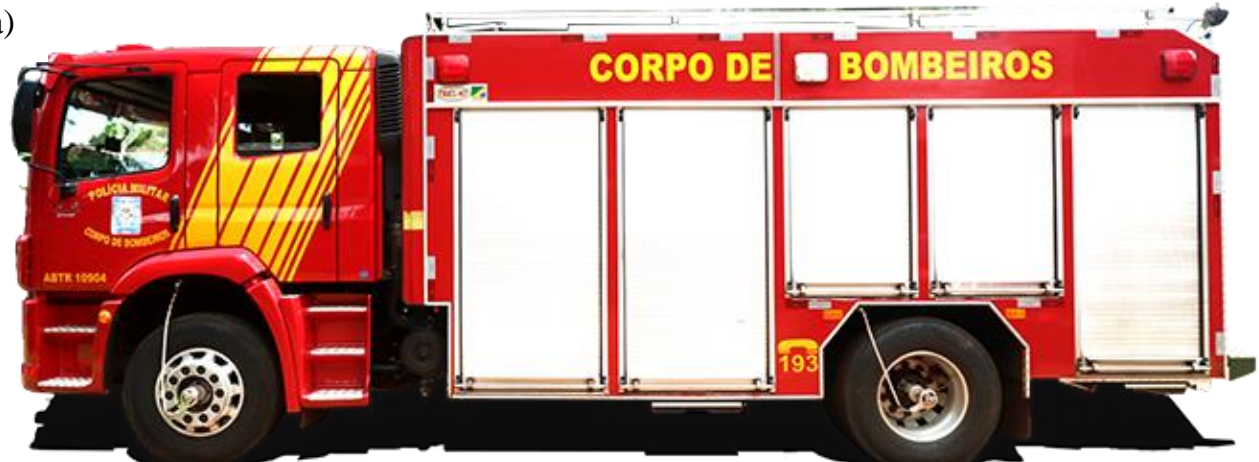

b)

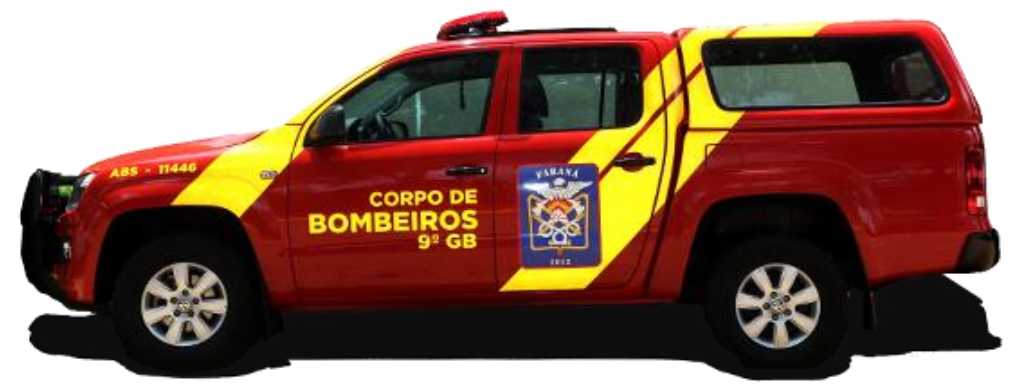

Source: Fire Department of the Military Police of Paraná (2020), adapted by the authors.

Figure 2. a) Fire engine; b) Auto Search and Rescue (SAR).

Figura 2. a) Auto Bomba Tanque e Resgate (ABTR); b) Auto Busca e Salvamento (ABS).

In Curitiba, the Fire Department of the Military Police of Paraná does not have watchtowers. The request for emergencies is made through the number 193, with the general public being the main actors in the detection of vegetation fires. After screening the request, the vehicles are dispatched according to their availability and proximity to the emergency.

In every occurrence attended by the fire department, a general record of occurrence is generated. Among the various information contained therein, there is the name of the team members, time of the calling, time of arrival and departure at and from the site, estimated burnt area, equipment and amount of water used. However, the insertion of every data is not mandatory. 
In this study, data collection occurred through the System of Registration and Statistics of the Fire Department of the Military Police of Paraná (SYSBM-CCB, 2016), which contains the general records of occurrences classified as "environmental fires", from 2011 to 2015.

Based on the individual analysis of each record, a classification was carried out in order to validate vegetation fires, since the classification used by the fire department in the analyzed period encompassed, in addition to vegetation fires, fires in different materials, such as residential and industrial waste. For this classification it was taken into account the description of the situation found by the fire department on site, as well as different information contained in the record that could help this consistency.

When the validated data was obtained, the following information was collected: presence of intervention by the firefighting team, time of the calling, arrival and departure of the firefighting team at and from the site, equipment and amount of water used, and estimated burnt area.

The burnt area is estimated by the interventionist team through an on-site assessment, usually visual, without the use of equipment such as tape measures or portable tracking device.

The occurrence record on the online platform of the SYSBM, version 3.31, determines that the burnt area should be reported in square meters. However, in several records, divergences were observed in registers related to the burnt area, indicating a possible misconception by the team when filling the necessary information. This is mainly related to the unit of measurement of the area being mistaken for hectare and bushel. Thus, we decided to take into account only the burnt areas of records that presented values equal to or greater than $100 \mathrm{~m}^{2}$ in order to avoid records mistakenly filled out, since two-digit values may be related to mistakes regarding the measurement unit.

The burnt area was distributed in classes according to the classification of Ramsey and Higgins (1981) (Table 1). The greater the concentration of records in the smaller classes, the better the firefighting efficiency.

The interval comprising the time of the calling and the team's arrival at the site provides the attack time (AT), which presents the mobilization time taken from the calling until the first attack. This variable was distributed according to the classification of Lima and Soares (1992) in five classes with different times of duration (Table 1). We also obtained the mean AT from the records containing the necessary information.

The period comprised from the arrival of the team at the site until their departure corresponds to the combat time (CT), according to Table 1 (LIMA and SOARES, 1992). The mean CT was also obtained from the records containing the necessary information.

Table 1. Distribution of burnt area, attack time and combat time in classes.

Tabela 1. Distribuição da área queimada, tempo de ataque e do tempo de combate em classes.

\begin{tabular}{cccc}
\hline Class & Burnt area (hectare) & Attack time (minutes) & Combat time (minutes) \\
\hline I & $0-0.09$ & $0-30$ & $0-60$ \\
II & $0.1-4.0$ & $31-60$ & $61-120$ \\
III & $4.1-40.0$ & $61-120$ & $121-480$ \\
IV & $40.1-200.0$ & $121-480$ & $>480$ \\
V & $>200.0$ & $>480$ & - \\
\hline
\end{tabular}

Source: adapted from Ramsey and Higgins (1981) and Lima and Soares (1992).

The values of the burnt area, AT and CT were submitted to the Shapiro-Wilk test of normality. Data normality was not verified even after base 10 logarithmic transformation of the values, so the AT and CT were correlated with the burnt area through Spearman's correlation coefficient at a 5\% significance level using the R program. In addition, the mean values of AT and CT were distributed according to the burnt area classes in order to verify the behavior of the means in relation to the burnt area classes.

The equipment used in the intervention of each occurrence, regardless of the type of affected vegetation and local edaphoclimatic characteristics, were grouped and classified as: smothering equipment, use of water, and counter-firing technique. The mean CT in the use of each fire-extinguishing method was obtained.

In occurrences where water was used, the mean amount used was estimated and distributed according to the burnt area class of each record. The amount of water used and the amount of burnt area were subjected to the Shapiro-Wilk test of normality, which found no normality in the data even after base 10 logarithmic transformation of the values. Thus, using the R program, the application of Spearman's correlation coefficient was performed at a $5 \%$ significance level between the amount of water used and the burnt area. 


\section{RESULTS}

After the individual analysis of each general occurrence register (GOR), 1,255 records (56.3\%) of the total occurrences classified by the fire department as environmental fires were found to be useful to this study; the other $43.7 \%$ referred to fires in other types of materials. Based on this verification, it was possible to classify the records used as vegetation fires. 1,074 records $(85.6 \%)$ presented fires that were extinguished by the teams that responded to the emergency call.

Of 1,074 records of vegetation fires that presented intervention by the teams, $477(44.4 \%)$ had information on the estimated burnt area with values equal to or greater than $100 \mathrm{~m}^{2}$, indicating a mean value of $2,399.21 \mathrm{~m}^{2}$ per record. Out of this total, 77 (7.2\%) had burnt area values lower than $100 \mathrm{~m}^{2}$, and $520(48.4 \%)$ had no burnt area values

According to Ramsey and Higgins' (1981) classification, class I was the most representative, accounting for $233(48.9 \%)$ of the records that presented intervention and burnt area information, followed by classes II, III and IV, which presented 187 (39.2\%), $54(11.3 \%)$ and 3 (0.6\%) records, respectively.

Of 1,074 records of vegetation fires with intervention by the fire department teams, 1,055 (98.2\%) presented complete information on attack and combat time.

The mean AT was 14.1 minutes per record. According to the classification of Lima and Soares (1992), $1,013(96.0 \%)$ records were found to belong to class I ( 0 to 30$)$ and $42(4.0 \%)$ to class II (31 to $60 \mathrm{~min}$ ).

The mean CT was 29.9 minutes per record. According to the classification of Lima and Soares (1992), $954(90.4 \%)$ records were found to belong to class I ( 0 to $60 \mathrm{~min}), 85(8.1 \%)$ records to class II (61 to $120 \mathrm{~min}$ ), and $16(1.5 \%)$ records to class III (121 to $480 \mathrm{~min})$.

It was found that, out of the 477 occurrences that were validated with burnt areas, $470(98.5 \%)$ presented information on attack time and combat time, allowing the means of these variables to be distributed in relation to the class of burnt area per fire (Table 2).

Table 2. Distribution of records in burnt area classes compared to mean attack and combat times.

Tabela 2. Distribuição dos registros nas classes de área queimada em comparação com a média de tempo de ataque e tempo de combate.

\begin{tabular}{lccc}
\hline Burnt area classes & $\mathbf{N}^{\mathbf{0}}$ & $\begin{array}{c}\text { AT } \\
(\mathbf{m i n})\end{array}$ & $\begin{array}{c}\text { CT } \\
(\mathbf{m i n})\end{array}$ \\
\hline I $(0-0.09$ ha $)$ & 229 & 14.27 & 23.42 \\
II $(0.1-4.0$ ha $)$ & 185 & 15.14 & 35.90 \\
III $(4.1-40.0$ ha $)$ & 53 & 15.94 & 56.85 \\
IV $(40.1-200.0$ ha $)$ & 3 & 15.33 & 123.67 \\
V $(>200.0$ ha $)$ & 0 & - & - \\
\hline Total & $\mathbf{4 7 0}$ & $\mathbf{1 4 . 8 0}$ & $\mathbf{3 2 . 7 4}$ \\
\hline
\end{tabular}

Source: SYSBM-CCB (2016), prepared by the authors.

Spearman's correlation coefficient was applied for the absolute values of burnt areas with AT and CT. The results pointed out that there was no significant correlation at a 5\% significance level between the burnt area and the AT $(r=0.07)$, but there was one between the burnt area and the CT $(\mathrm{r}=0.48)$. Between AT and CT there was no significant correlation $(r=-0.009)$.

Regarding the fire-extinguishing methods, it was verified that, of the records in which there was intervention, $792(73.7 \%)$ presented information on the main equipment used in firefighting, which after classification and grouping were distributed according to Table 3 .

Table 3. Distribution of the fire-extinguishing methods.

Tabela 3. Distribuição dos principais meios de extinção.

\begin{tabular}{lcc}
\hline Main fire-extinguishing methods & $\begin{array}{c}\text { Number } \\
\text { of records }\end{array}$ & $\begin{array}{c}\text { \% of } \\
\text { records }\end{array}$ \\
\hline Smothering equipment & 307 & 38.8 \\
Water usage & 266 & 33.6 \\
Smothering equipment and water (combined) & 214 & 27.0 \\
Smothering equipment and counter firing-technique (combined) & 5 & 0.6 \\
\hline Total & $\mathbf{7 9 2}$ & $\mathbf{1 0 0}$ \\
\hline
\end{tabular}

Source: SYSBM-CCB (2016), prepared by the authors.

FLORESTA, Curitiba, PR, v. 51, n. 4, p. 900-909, out/dez 2021. 
When distributing the mean CT according to the fire-extinguishing methods used, it was observed that $98.7 \%$ of the records that presented information on fire-extinguishing methods also presented information on CT. It was found that smothering equipment was used with a mean CT of 29.0 minutes, water was used with a mean CT of 23.7 minutes, smothering equipment and water combined had a mean CT of 41.8 minutes, and smothering equipment and counter-firing technique combined had a CT mean of 54.0 minutes.

Of the records that showed water usage alone or combined with the smothering equipment, 241 showed the amount of water used, with a mean of $1,186.56$ liters per fire.

Of all the occurrences with intervention, 111 records presented information both on the amount of water used and burnt area: class I presented 55 records and a mean water usage of 818.91 liters; class II presented 47 records and a mean water usage of 1,889.36 liters; and class III presented 9 records and a mean water usage of 2,277.77 liters. Spearman's correlation coefficient showed significant correlation between the variables $(r=0.51)$ at a $5 \%$ level.

\section{DISCUSSION}

A satisfactory efficiency in firefighting in Curitiba was verified due to the fact that the representativeness of each class presents decreasing values. This indicates good efficiency in extinguishing vegetation fires, as the greater the grouping in higher classes, the less efficient the combat (LIMA and SOARES, 1992; TETTO et al., 2012b).

At national and international levels, there are few studies that address vegetation fires in urban areas and wildland-urban interface, hindering reliable comparisons in relation with the present study. Thus, this study was limited to comparisons with other studies that present study areas with different characteristics regarding vegetation type, dimensions of vegetation areas, and edaphoclimatic characteristics.

Table 4 presents the results obtained in other studies following the same burnt area classification used in this study, and Table 5 the results obtained by different studies on the mean burnt area per fire.

Table 4. Results of burnt area classes obtained by different studies in comparison with the present study.

Tabela 4. Resultados das classes de área queimada obtidos por diferentes estudos em comparação com o presente estudo.

\begin{tabular}{ccc|ccccc}
\hline & Search & & \multicolumn{4}{c}{ Burnt area classes (\%) } \\
\hline Authors & Study area & Period & I & II & III & IV & IV \\
\hline The present study & Curitiba, PR & $2011-2015$ & 48.9 & 39.2 & 11.3 & 0.6 & 0 \\
Lima and Soares (1992) & Brazil & $1984-1987$ & 7.9 & 39.6 & 30.9 & 14.6 & 7.0 \\
Magalhães et al. (2011) & PNSC, MG & $2002-2008$ & 0.0 & 9.6 & 28.8 & 19.6 & 42.0 \\
Tetto et al. (2012b) & Telêmaco Borba, PR & $1965-2009$ & 51.3 & 43.5 & $-*$ & $-*$ & $-*$ \\
Tebaldi et al. (2013) & State CUs, ES & $2005-2009$ & 19.0 & 25.0 & 25.0 & 19.0 & 12.0 \\
Lima et al. (2018) & Federal CUs, Brazil & $2008-2012$ & 4.3 & 44.9 & 30.5 & 10.4 & 9.9 \\
Torres et al. (2018) & PESB, MG & $2007-2015$ & 0.0 & 17.7 & 47.1 & 32.3 & 2.9 \\
\hline
\end{tabular}

Note: *value not presented in the study; Conservation Units (CUs); Serra da Canastra National Park (PNSC); Serra do Brigadeiro State Park (PESB).

Table 5. Results of the mean burnt area per fire obtained by different studies in comparison with the present study.

Tabela 5. Resultados das médias de área queimada por ocorrência obtidas por diferentes estudos em comparação com o presente estudo.

\begin{tabular}{|c|c|c|c|}
\hline \multicolumn{3}{|c|}{ Search } & \multirow{2}{*}{$\begin{array}{c}\text { Burnt area/occurrence } \\
\text { (ha) }\end{array}$} \\
\hline Authors & Study area & Period & \\
\hline The present study & Curitiba, PR & $2011-2015$ & 0.2 \\
\hline Lima and Soares (1992) & Brazil & 1984-1987 & 66.7 \\
\hline Ozturk et al. (2010) & Turkey & 1938-1998 & 23.5 \\
\hline Tetto et al. (2012a) & Paraná & $2005-2010$ & 3.1 \\
\hline Tetto et al. (2012b) & Telêmaco Borba, PR & 1965-2009 & 1.7 \\
\hline Castillo-Soto et al. (2012) & Chile & $1976-2010$ & 12.2 \\
\hline Rodríguez et al. (2013) & Pinar del Río, Cuba & 2002-2011 & 18.9 \\
\hline Nanvonamuquitxo et al. (2013) & Zambezia, Mozambique & 2007-2011 & 64.1 \\
\hline Lima et al. (2018) & Federal CUs, Brazil & 2008-2012 & 613.6 \\
\hline Santos et al. (2019) & Londrina, PR & $2005-2014$ & 1.7 \\
\hline Santos et al. (2019) & Pisa, Italy & $2005-2014$ & 2.1 \\
\hline
\end{tabular}

Note: Conservation Units (CUs).

FLORESTA, Curitiba, PR, v. 51, n. 4, p. 900-909, out/dez 2021. 
In comparison with other study areas, Curitiba has vegetation areas that tend not to present large extensions, differently from rural areas intended for forest cultivations and conservation units, thus favoring a higher concentration in classes I and II due to fire propagation limitations. In addition, the Cfb climate classification of Curitiba assists in minimizing fire spread and provides better conditions for firefighting if compared to the climate classifications of the other study areas.

Another relevant factor is that detection in the study area comes from the general public, which provides rapid intervention by the fire department and reduces the perimeter affected by fires, unlike forest cultivations and conservation units in general.

Regarding the burnt area classes (Table 4), the results obtained in this study were close to those of Tetto et al. (2012b), who analysed the records of a forestry company. Even though the company's areas are not located in urban zones, the economic importance of forest cultivations tends to lead to more resources being allocated to firefighting, as well as to a more efficient strategic planning concerning the prevention and firefighting of vegetation fires, in comparison to Brazilian conservation units, which means a more efficient combat analogous to this study. The results obtained by Lima and Soares (1992) refer to an area of national coverage. Such area encompasses different plant typologies, along with different edaphoclimatic, land use and occupation characteristics, all of which differ from the specificities Curitiba presents.

Castillo-Soto et al. (2015) observed that, in the region of Valparaíso, Chile, from 1998 to 2009, 77.76\% of the records $(4,560)$ presented burnt areas smaller than one hectare, conforming to Ramsey and Higgins' I and II classes (1981). This indicates good firefighting efficiency in the region, which presents considerable areas of wildland-urban interface.

Regarding occurrence-related burnt areas (Table 5), the different studies indicate higher values than the ones presented in this study. The most similar results are the ones obtained by Santos et al. (2019) in Londrina, Paraná, and in Pisa, Italy, which are sites that also have urban areas and a wildland-rural interface, akin to Curitiba. Furthermore, the result obtained by Tetto et al. (2012b) also points to a greater similarity when compared to other studies due to referring to a forestry company, as previously discussed. 72.37\% of Rodríguez et al. (2013) records referred to forest cultivations areas in Pinas del Río, but registered a lower combat efficiency than that presented by Tetto et al. (2012b) and this study. Tetto et al. (2012a) presents a result lower than most of the other studies (3.1 ha/occurence), as it encompasses the entire state of Paraná, including urban areas similar to Curitiba.

The other values presented by the studies referred to areas with high vegetation levels and that do not have commercial purposes, such as conservation units (LIMA et al., 2018) in Brazil (LIMA and SOARES, 1992), Turkey (OZTURK et al., 2010), Chile (CASTILLO-SOTO et al., 2012) and Zambézia, Mozambique (NANVONAMUQUITXO et al., 2013).

The AT obtained in this study showed good efficiency regarding the beginning of combat, since $96.0 \%$ of the occurrences were within the parameters of class I ( 0 to $30 \mathrm{~min}$ ) and the other $4.0 \%$ within class II ( 31 to 60 $\min )$.

Table 6 presents the results obtained by different studies in comparison to the ones obtained by this study regarding mean AT and CT and class I concentration (Table 2).

Table 6. Results of mean attack time, combat time, and class I concentration from different studies compared to this study.

Tabela 6. Resultados das médias de tempo de ataque e tempo de combate obtidas por diferentes estudos, bem como a concentração na classe I, em comparação com o presente estudo.

\begin{tabular}{ccc|cc|cc}
\hline & Study & & \multicolumn{2}{c|}{ AT } & \multicolumn{2}{c}{ CT } \\
\hline Authors & Location & Period & $\begin{array}{c}\text { Mean } \\
(\mathbf{m i n})\end{array}$ & $\begin{array}{c}\text { Class I } \\
(\boldsymbol{\%})\end{array}$ & $\begin{array}{c}\text { Mean } \\
(\mathbf{m i n})\end{array}$ & $\begin{array}{c}\text { Class I } \\
(\boldsymbol{\%})\end{array}$ \\
\hline The present study & Curitiba, PR & $2011-2015$ & 14.1 & 96.0 & 29.9 & 90.4 \\
Lima and Soares (1992) & Brazil & $1984-1987$ & 73.3 & 48.6 & 221.8 & 25.2 \\
Magalhães et al. (2011) & PNSC, MG & $2002-2008$ & 252.8 & 23.5 & $1,610.6$ & 0.0 \\
Tetto et al. (2012b) & Telêmaco Borba, PR & $1965-2009$ & 33.0 & $-*$ & 114.0 & 21.9 \\
Lima et al. (2018) & Federal CUs, Brazil & $2008-2012$ & 194.8 & 38.3 & $1,012.5$ & 24.5 \\
\hline
\end{tabular}

Note: * value not presented in the study; Conservation Units (CUs); Serra da Canastra National Park (PNSC).

This study's mean AT was lower than the ones from the other studies, while class I concentration was higher. This is mainly due to the fact that the AT tends to be related to the proximity between the site and the operational units of the municipality's fire department, as well as the facility of access to the areas. However, as the study area is a metropolis, the coverage of the road network is extensive. In addition, if they are not engaged

FLORESTA, Curitiba, PR, v. 51, n. 4, p. 900-909, out/dez 2021. 
in other situations, the teams of the fire department tend to be fully available, not requiring a long mobilization time, unlike the reality of other study areas where teams on standby might not always be available.

The work of Tetto et al. (2012b) provides the closest value to the one obtained in this study, as its hypothesis is, again, related to the importance of forest cultivation for the responsible company, which promotes greater attention towards the dimensioning of resources for firefighting, increasing the availability and coverage of interventionist teams.

Areas of conservation units, study object of Magalhães et al. (2011) and Lima et al. (2018), had, respectively, the highest mean AT values, indicating a low efficiency in the assignment and mobilization of the interventionist team to the site, a fact that may be directly related to local characteristics.

A mean CT of 29.9 minutes and a $90.4 \%$ concentration of records in class I (Table 6) constitute satisfactory results for Curitiba, as class I also had the highest concentration of CT, and the mean CT value is lower than the ones registered in other study areas. It should be noted that Magalhães et al. (2011) did not observe fires that had a CT lower than 60 minutes in Serra da Canastra National Park, leading to a higher concentration of fires with a CT greater than 480 minutes $(59.18 \%)$.

When analyzing the distribution of AT and CT means in comparison with the burnt area classes, the mean ATs were found to be similar to each other regardless of the burnt area class, demonstrating that the expansion of the burnt area had no relation with the AT from the study area, as statistically proven by Spearman's correlation coefficient.

This study could not measure detection and communication time, suggesting that these variables have a greater influence on fire dynamics than the AT, since the means of the study area were similar for the different burnt area classes. In addition, the AT is related to the time of first arrival of the interventionist team at the site and does not take into account the number of personnel employed to extinguish the fire.

Lima et al. (2018) found a correlation of 0.48 between these variables in Brazilian CUs. However, the mean AT was of 194.8 minutes, much higher than the one from Curitiba, where the fire would tend to have a higher intensity and, consequently, a higher propagation speed.

Regarding CT, the larger the burnt area class, the longer the combat time, which demonstrates a lower combat efficiency in larger burnt areas. A positive and significant correlation between burnt area and CT was also observed through the use of Spearman's correlation coefficient, similar to the result obtained by Lima et al. (2018) in their study area $(r=0.62)$.

In addition, no significant correlation was observed between AT and CT, which suggests there are other variables that might influence a higher CT, similarly to what was observed between AT and burnt area. Lima et al. (2018) found a correlation of 0.51 between the variables in their study.

Regarding the fire-extinguishing methods used, smothering equipment were found to be present in $38.8 \%$ of the records containing information on the methods employed. Smothering was also said to be employed in $27 \%$ of the records together with water, and in $0.6 \%$ of the records combined with the counter-firing technique, amounting to a presence of $66.4 \%$ in the records. The exclusive use of water was said to occur in $33.6 \%$ of the records. In turn, water combined with smothering equipment amounted to $60.6 \%$ of the records. This result demonstrates the need for water and smothering equipment to be adequately conserved, as well as the need for adequate training for their use, since they are the main fire-extinguishing methods employed in the study area.

It was found that the mean CT was shorter when water was used exclusively (23.7 minutes), thus showing the high efficiency of this fire-extinguishing method compared to others.

The mean amount of water used, 1,186.56 liters per record that contained this information, demonstrates the importance of water storage containers having a volume greater than the mean obtained, since there is not always a water source, either artificial or natural, near the site of the vegetation fire (SOARES et al., 2017).

When analyzing the mean amount of water used according to the burnt area classes, even class I fires were found to demand an average of 818.91 liters of water per fire. The larger the burnt area, the greater the need for water use. Thus, strategic planning regarding firefighting should foresee water replenishment strategies (SOARES et al., 2017).

\section{CONCLUSION}

Based on the results obtained, we concluded that:

- The firefighting of vegetation fires in Curitiba presents satisfactory efficiency, since most records indicate a burnt area inferior or equal to four hectares, mean AT of 14.1 minutes, and mean CT of 29.9 minutes;

- AT was not a determining factor for burnt area increase, which may be related to factors not considered in this study such as detection and communication time; 
- The main fire-extinguishing methods used in combat operations were smothering equipment $(66.4 \%$ of the records containing this information) and water (60.6\% of the records), highlighting the importance of constant maintenance and training in the use of these equipment given their high use rate in the study area;

- The mean amount of water used was 1,186.56 liters, indicating the minimum size required for water storage containers, as well as the need for advance planning regarding water supply sources;

- In order to improve firefighting processes, both standardization and mandatory filling of all information required in the records are needed for further evaluation and comparison.

\section{ACKNOWLEDGMENTS}

The authors would like to thank the Academic Publishing Advisory Center (Centro de Assessoria de Publicação Acadêmica, CAPA - www.capa.ufpr.br) of the Federal University of Paraná (UFPR) for assistance with English language translation and editing.

\section{REFERENCES}

BOWMAN, D. M. J. S.; BALCH, J.; ARTAXO, P.; BOND, W. J.; COCHRANE, M. A.; D’ANTONIO, C. M.; DEFRIES, R.; JOHNSTON, F. H.; KEELEY, J. E.; KRAWCHUK, M. A.; KULL, C. A.; MACK, M.; MORITZ, M. A.; PYNE, S.; ROOS, C. I.; SCOTT, A. C.; SODHI, N. S.; SWETNAM, T. W. The human dimension of fire regimes on Earth. Journal of Biogeography, [S.I.], v. 38, p. 2223 - 2236, 2011.

CASTILlO-SOTO, M. E.; GARFIAS, R. S.; JULIO, G. A. GONZÁLEZ, L. R. Análisis de grandes incendios forestales en la vegetación nativa de Chile. Interciencia, Caracas, v. 37, n. 11, p. 796 - 804, 2012.

CASTILlO-SOTO, M. E.; RODRIGUEZ-SILVA, F. Quantitative analysis of forest fire extinction efficiency. Forest Systems, Espanha, v. 24, n. 2, e032, 2015.

CORPO DE BOMBEIROS DO PARANÁ. Estrutura organizacional. Disponível em: < http://www.bombeiros.pr.gov.br/>. Acesso em: 25/04/2020.

FIDALGO, E. S. Risco de incêndios na interface urbano-florestal: reflexão conceptual. Territorium, Coimbra, v. 20, p. $101-114,2013$.

GRISE, M. M.; BIONDI, D.; ARAKI, H. Índices espaciais da floresta urbana de Curitiba-PR. Revista da Sociedade Brasileira de Arborização Urbana, Curitiba, v. 13, n. 4, p. 1 - 14, 2018.

INSTITUTO BRASILEIRO DE GEOGRAFIA E ESTATÍSTICA (IBGE). Cidades: Curitiba. Disponível em: $<$ https://cidades.ibge.gov.br/brasil/pr/curitiba>. Acesso em: 10/03/2020.

LIMA, G. S.; SOARES, R. V. Avaliação da eficiência de combate aos incêndios florestais no Brasil. Floresta, Curitiba, v. 22, n. 1/2, p. 25 - 38, 1992.

LIMA, G. S.; TORRES, F. T. P.; COSTA, A. G.; FÉLIX, G. A.; DA SILVA JÚNIOR, M. R. Avaliação da eficiência de combate aos incêndios florestais em unidades de conservação brasileiras. Floresta, Curitiba, v. 48, n. 1, p. 113 - 122, 2018.

LOURENÇO, L.; FERNANDES, S.; BENTO-GONÇALVES, A.; CASTRO, A.; NUNES, A.; VIEIRA, A. Causas de incêndios florestais em Portugal continental. Análise estatística da investigação efetuada no último quindénio (1996 a 2010). Cadernos de Geografia, Coimbra, n. 30/31, p. 61 - 80, 2012.

MAACK, R. Geografia física do Estado do Paraná. Ponta Grossa: UEPG, 4 ed., 2012. 526 p.

MAGAlHÃES, S. R.; LIMA, G. S.; RIBEIRO, G. A. Avaliação do combate aos incêndios florestais no Parque Nacional da Serra da Canastra. Floresta Ambient., Seropédica, v. 18, n. 1, p. 80 - 86, 2011.

NANVONAMUQUITXO, S. J.; ROJAS, F. G.; RODRÍGUEZ, M. P. R. Perfil de los incendios de la vegetación em la província de Zambézia, Mozambique de 2007 a 2011. Revista Cubana de Ciencias Forestales, Cuba, v. 1, n. 2, p. $1-13,2013$.

OZTURK, M.; GUCEL, S.; KUCUK, M.; SAKCALI, S. Forest diversity, climate change and forest fires in the Mediterranean region of Turkey. Journal of Environmental Biology, India, v. 31, p. 1 - 9, 2010.

SANTOS, J. F. L. dos; TETTO, A. F.; BERTACCHI, A.; BATISTA, A. C.; SOARES, R. V. Comparison of forest fire profiles in Londrina, Brazil and Pisa, Italy. Floresta Ambient., Seropédica, v. 26, n. 2, e20170607, 2019. 
SOARES, R. V.; BATISTA, A. C.; TETTO, A. F. Incêndios florestais: controle, efeitos e uso do fogo. Curitiba. 2 ed. revisada, 2017. $255 \mathrm{p}$.

SISTEMA DE REGISTRO DE OCORRÊNCIAS E ESTATÍSTICAS DO CORPO DE BOMBEIROS (SYSBMCCB). Registros de 2011 a 2015. Disponível em: <http://www.bombeiroscascavel.com.br/registroccb/>. Acesso em: 05/10/2016.

TEBALDI, A. L. C.; FIEDLER, N. C.; JUVANHOL, R. S.; DIAS, H. M. Ações de prevenção e combate aos incêndios florestais nas unidades de conservação estaduais do Espírito Santo. Floresta Ambient., Seropédica, v. 20, n. 4, p. 538 - 549, 2013.

TETTO, A. F.; BATISTA, A. C.; SOARES, R. V. Ocorrência de incêndios florestais no estado do Paraná, no período de 2005 a 2010. Floresta, Curitiba, v. 42, n. 2, p. 391 - 398, 2012a.

TETTO, A. F.; SOARES, R. V.; BATISTA, A. C.; WENDLING, W. T. Eficiência do combate aos incêndios florestais, no período de 1965 a 2009, na Fazenda Monte Alegre, Paraná. Scientia Forestalis, Piracicaba, v. 40, n. 96, p. 483 - 489, 2012b.

TORRES, F. T. P.; TORRES, C. M. M. E.; LIMA, G. S.; MARTINS, S. V.; MENDES, A. E. O.; PADOVANI, M. T.; SIQUEIRA, R. G.; MOREIRA, G. F.; VALVERDE, S. R. Análise do perfil dos incêndios florestais no Parque Estadual da Serra do Brigadeiro e entorno (MG). Ciência Florestal, Santa Maria, v. 28, n. 3, p. 1008 1021, 2018.

RAMSEY, G. S.; HIGGINS, D. G. Canadian forest fire statistics. Ontario: Canadian Forestry Service, 1981.71 p. Information Report PI-X-9.

RODRÍGUEZ, M. P. R.; SOARES, R. V.; BATISTA, A. C.; TETTO, A. F.; BECERRA, L. W. M. Comparação entre o perfil dos incêndios florestais de Monte Alegre, Brasil, e de Pinar del Río, Cuba. Floresta, Curitiba, v. 43, n. 2, p. $231-240,2013$.

VÉLEZ, R. La defensa contra incendios forestales: fundamentos y experiencias. Madrid: McGraw-Hill, 2 ed., 2009. $841 \mathrm{p}$ 